\title{
How Should We Start the "Do-Over?" Is Training the First Step?
}

\author{
Richard D. Krugman ${ }^{1,2} \cdot$ Lori E. Poland ${ }^{1}$
}

Published online: 20 August 2020

(C) The Author(s) 2020

In Issue No. 1 of this volume of International Journal on Child Maltreatment, we described the origin and mission of the National Foundation to End Child Abuse and Neglect that we co-founded 2 years ago (Krugman and Pound 2020). It is our belief that the child protection system in the USA, which was described 30 years ago as being in an emergency condition (US Advisory Board on Child Abuse and Neglect 1990), is still not protecting children as it should be. The reasons for that failure are many.

As a new foundation with the mission of ending child abuse and neglect in our lifetime, we were not interested in funding programs or systems that were contributing to the status quo. We posed a question to our colleagues in the field: If we were starting over, knowing everything we know now after 50 years of experience, how should we design the ideal approach to training, research, clinical care, and prevention? We used a national peer review panel to review letters of intent (59) from which 25 full papers were solicited. The six papers chosen as best in the areas of prevention, clinical care, and research (two in each category) were published in a special issue of this journal (Vol. 3, No. 1).

There were four submissions in the training category in the first round, all of which were deemed insufficiently innovative. Each took what the review panel believed was an unduly narrow approach focused on training for a single profession (e.g., psychology; social work). A second round of papers was solicited. After peer review, three papers were judged to be worthy of presentation in this issue of the journal (winner:

This issue of the International Journal on Child Maltreatment: Research, Policy, and Practice is focused on disruption papers that are the products of a US national competition for innovation in training related to the prevention and treatment of child abuse and neglect. Issue No. 1 of this volume (No. 3) of IJCM featured disruption papers on research, prevention, and treatment, all of which were selected by expert panels in the initial national competition.

The sponsor of the competitions was The National Foundation to End Child Abuse and Neglect (EndCAN), which is led by its co-founders, who are the authors of this introduction to the issue. Krugman is the chair of the board of directors, and Poland is the executive director. With Desmond K. Runyan, Krugman is also coeditor of this special issue.

Richard D. Krugman

richardkrugman@endcan.org

Extended author information available on the last page of the article 
Schelbe et al.; honorable mentions: Christian et al.; Gardner et al.) Each of these papers describes a multidisciplinary approach — and each in a different way.

Apart from the EndCAN competition in the USA, Katz et al. submitted a manuscript to $I J C M$ on a community intervention in Israel that provided perspective-changing experiences for social work students and that also appeared to alter the thinking and practice of the community social workers who mentored them. With the integration of the efforts of community residents and of faculty and students, the approach (Strong Communities for Children; see Kimbrough-Melton and Melton 2015) blends the experiences of community and university in a manner that potentially strengthens and enriches both and that goes well beyond the ordinary boundaries of social work (Katz et al. 2019). ${ }^{1}$

As leaders of EndCAN, we asked Des Runyan, one of the principal reviewers in our disruption-paper competition, to write a commentary summarizing these four essays on training and what their impact could or should be going forward. We are grateful to all of our colleagues who submitted letters of intent and who ultimately wrote disruption papers. Some readers will examine the articles that resulted and conclude that they are both individually and collectively too disruptive; others may find them not disruptive enough. We hope that the approaches described here can be tested and applied to a field that needs transformative help.

\section{Reflections on This Disruption Process and the Challenges Ahead}

Training and education about child abuse and neglect in the USA are stunningly fragmented. Each professional school (e.g., social work; medicine; law) includes the bare minimum information or exposure necessary for accreditation of that professional school. Most medical schools have 1 to 4 hours of lecture in the first 2 years, and an hour or so on the pediatric rotation of the third (clinical) year. The several dozen medical schools that have child abuse pediatricians and related fellowship training may offer a 2- to 4-week elective for the 4th-year students going into pediatrics, psychiatry, emergency medicine, or another medical specialty involved in identification or assessment of child maltreatment. The focus of training in such instances is about recognition and mandatory reporting, not prevention and treatment.

The front-line child protection work in the USA is mostly done by entry-level child welfare workers, who in Colorado now participate in a 6-week core course at a child welfare academy. The clinical psychologists and other mental health professionals obtain their training in graduate and internship programs that may or may not provide experience in evidence-based treatment for children and families. Depending on the community or county

\footnotetext{
${ }^{1}$ The initial trial of Strong Communities in northwestern South Carolina was based in a university-based interdisciplinary institute with a doctoral program in international family and community studies. That program in turn was led by a core faculty accustomed to interdisciplinary work and including members who uniformly had a strong non-disciplinary (interdisciplinary) identification. The faculty who were involved in the initiative in its early years and their successors have doctoral degrees in education, family and community studies, law, medicine, nursing, social work, theology, and clinical, community, and developmental psychology and other professional identities in community planning, political theory, public health, and sociology. The advisory committee, which Krugman chaired, consisted of scholars in anthropology, pediatrics, sociology, and clinical and community psychology.
} 
that one lives in, the "system" for treating children and families may depend in large part on their luck in having access to professionals who collaborate and share common perspectives on the nature of child maltreatment and responses to it.

The EndCAN effort to "disrupt" has provided some good ideas. In our view, however, none has been nearly disruptive enough. Perhaps, an example from medicine of disruptive training could help to stimulate more creative ideas. Medical education during the twentieth century was heavily influenced by Abraham Flexner, who critiqued medical education in the USA between 1908 and 1910 and found it to be dismal. Flexner's report put into place a 4year curriculum leading to the MD degree: 2 years of education in basic sciences, taught one science (e.g., anatomy) at a time; in the third year, clinical sciences (e.g., internal medicine; surgery), also taught one at a time; in the fourth year, electives and "sub-internships" in clinical practice. Medical school was followed by 3 to 5 years of specialty training. At the end of this training, opportunities existed for even more training in subspecialty fellowships (e.g., cardiology; rheumatology; oncology). The inevitable outcome of this process was the recognition in the 1960s that there were too many medical specialists and subspecialists and not enough physicians entering primary care practice (i.e., family medicine, internal medicine, or pediatrics).

Enter Henry K. Silver, MD. A collaborator with Henry Kempe in the seminal article on the battered-child syndrome (Kempe et al. 1962), Silver was a pediatrician who focused much of his career on the primary care shortage. He recognized that the amount of time that physicians in training spent with specialist mentors and the differentials in salaries paid specialists and primary care providers meant that relatively few would choose a career in primary care practice. Even if they did, they were not prepared for the topics (e.g., developmental and psychosocial issues) and activities (e.g., anticipatory guidance; counseling) that predominate in primary care.

Silver's first disruption was to nursing education. Joining with Loretta Ford, RN, Silver started the first pediatric nurse practitioner program in the USA. Nurses who had a basic education in their profession and 5 years of experience in a general pediatric practice participated in a 4-month curriculum to train them in taking a history, doing a physical examination, and then asking and answering three basic questions:

1. Is this child sick or well?

2. If the child is sick, is the illness is mild or self-limited?

3. Does a physician need to see the child now or later?

Silver then replicated the approach with school nurses and created the School Nurse Practitioner Program (Silver and Nelson, 1971).

Since the initial two pediatric nurse practitioners were trained in 1965, the field has grown to include more than 250,000 advanced practice nurses in many adult and pediatric specialties in both outpatient and inpatient settings. Those in primary care have been able to provide $90 \%$ or more of the services that physicians were providing! The result, of course, has been a substantial increase in children's access to primary health care.

Silver's third experiment was to start the Child Health Associate (CHA) program (Silver and Hecker 1970). He believed that there were many young (and middle-aged) people in our society who knew that they wanted to be in health care and knew that they wanted to care for children. His CHA program began in 1969 and provided those with no nursing or other health care background a 3-year program of education. The first year was basic science 
education - but in the context of experiential learning in relation to history taking, physical examinations, and well care for children in several families whom the students initially met in the prenatal clinic and then followed throughout the students' 3 years of training. The second year was advanced therapeutics and behavioral and psychosocial clinical training, and the third year was a clinical internship with opportunities available in private and public clinical practices across the USA.

In conventional medical education, students who knew that they wanted to go into pediatrics had to wait 4 to 7 years to reach their goal. In contrast, after 3 years in the CHA curriculum, students were found to be able to do $95 \%$ of what a general pediatrician could do in the clinic and low-risk nursery care. Besides avoiding unnecessary opportunity costs because of prolonged education, CHA students incur less than half the tuition expenses borne by their peers who pursue the MD and pediatrics residency. Forty years after Silver undertook the innovation in CHA training, more than 1000 CHA professionals are in practice in the USA and around the world.

Finally, Silver applied to the Robert Wood Johnson Foundation in 1976 for funding to test the principles that he had learned in medical schools. Silver and his colleagues would create a 5-year program that would prepare physicians to be licensed to provide primary care for women (gyniatricians), children (pediatricians), seniors (geriatricians), and families (family physicians).

One of us (Krugman) was with him when a vice-president of the RWJ Foundation rejected the grant. The foundation executive proclaimed, "Medical education is just fine. We do not need to be experimenting with it," but Silver's work was disruptive to the process of medical education. Silver showed that the rules prescribing the content of "pre-med" education were unnecessary. Students with some (or even no) medical background could learn the material necessary for practice. Moreover, the curriculum could be tailored and streamlined so if students knew that they wanted to take care of children or women or seniors, they need not spend 4 years being a "stem cell" in a general curriculum before learning the principles of practice for the population of interest (Silver et al. 1979). Building on Silver's disruptions, most medical schools today have evolved far from the Flexnerian curricula of the twentieth century. They offer tracks and other innovations that are certainly no longer revolutionary; indeed, "mundane" may be a better descriptor.

How does Silver's work relate to what EndCAN was trying to do when we issued a call for disruption papers in the clinical, research, prevention, and training areas of professional practice related to child abuse and neglect? Given that each of the honored papers makes distinctive and positive but still insufficient contributions to resolution of the serious problems that the current child protection system has had for more than 30 years, what should happen now? Until we can actually measure the outcomes - health, mental health, and social — of the children and families who are entangled in the present system, it may lack incentives to change, much less innovate. Federal, state, and county governments spend billions of dollars supporting child protection systems that have no real accountability to either government or clients, yet the current approach is mandated by state laws that place responsibility for dealing with abuse and neglect on one agency and relegate all other professions and systems (e.g., health, mental health, and education) that could be part of the solution to be "mandatory reporters" of their suspicions only.

Perhaps, one lesson from all these papers is that we need to explore other approaches to child protection. The federal government (or a state or county government) could legislate the creation of a "shadow child protection system" somewhere. It would be 
built on the principles that the authors of all our papers have provided, and most importantly, it would measure the outcomes for children and families. A baby step towards a better future would be to mandate legislatively (as a condition of funding) that CPS measure outcomes (not just process). That could be another critical first step in resolving our decades-old national emergency.

Open Access This article is licensed under a Creative Commons Attribution 4.0 International License, which permits use, sharing, adaptation, distribution and reproduction in any medium or format, as long as you give appropriate credit to the original author(s) and the source, provide a link to the Creative Commons licence, and indicate if changes were made. The images or other third party material in this article are included in the article's Creative Commons licence, unless indicated otherwise in a credit line to the material. If material is not included in the article's Creative Commons licence and your intended use is not permitted by statutory regulation or exceeds the permitted use, you will need to obtain permission directly from the copyright holder. To view a copy of this licence, visit http://creativecommons.org/licenses/by/4.0/.

\section{References}

Katz, C., McLeigh, J. D., \& Ben-Arieh, A. (2019). Reflections on the traditional role of social workers in child protection: lessons learned from the Strong Communities Initiative in Israel. International Journal on Child Maltreatment: Research, Policy, and Practice, 2, 199-210.

Kempe, C. H., Silverman, F. N., Steele, B. F., Droegemueller, W., \& Silver, H. K. (1962). The battered-child syndrome. Journal of the American Medical Association, 181, 17-24.

Kimbrough-Melton, R. J., \& Melton, G. B. (2015). "Someone will notice, and someone will care": How to build Strong Communities for Children. Child Abuse \& Neglect, 41, 67-78.

Krugman, R. D., \& Pound, L. H. (2020). Can we have a "do-over"? Disrupting a half-century-old approach to child abuse and neglect. International Journal on Child Maltreatment: Research, Policy, and Practice, 3, 1-7.

Silver, H. K., \& Hecker, J. A. (1970). The pediatric nurse practitioner and the child health associate: new types of health professionals. Journal of Medical Education, 45, 171-176.

Silver, H. K., Ford, L. C., \& Stearly, S. G. (1967). A program to increase health care for children: the pediatric nurse practitioner. Pediatrics, 39, 756-760.

Silver, H. K., Makowski, E., McAfee, P., \& Krugman, R. D. (1979). Utilization of gyniatricians as primary care health providers for women. Journal of Reproductive Medicine, 22, 157.

Silver, H. K., \& Nelson, N. (1971). JONA: The journal of nursing administration, 1(3), 4-6.

U.S. Advisory Board on Child Abuse and Neglect. (1990). Child abuse and neglect: critical first steps in response to a national emergency. Washington, DC: U.S. Government Printing Office.

Publisher's Note Springer Nature remains neutral with regard to jurisdictional claims in published maps and institutional affiliations.

\section{Affiliations}

\section{Richard D. Krugman ${ }^{1,2} \cdot$ Lori E. Poland ${ }^{1}$}

1 The National Foundation to End Child Abuse and Neglect (EndCAN), PO Box 102428, Denver, CO 80250, USA

2 Department of Pediatrics, University of Colorado Anschutz Medical Campus, Aurora, CO, USA 